\title{
Workload Analysis at Biro Human Capital to Increase Productivity
}

\author{
Antonia Ratna Hanjani ${ }^{1}$ and Moses Laksono Singgih ${ }^{1}$
}

\begin{abstract}
PT XYZ is a company in Indonesia engaged in manufacturing. One strategy to support these activities is to adjust the workload of the existing work to increase productivity in this company. Workload is very influential on employee performance productivity because the environment and work capacity are aligned with productivity. If the burden received is too heavy, then employee productivity will decrease, whereas if the workload is balanced then employee productivity will increase. Workload Analysis is a method used to determine the time, effort, and resources needed by an organization in identifying the actual needs of Human Resources (HR) in quality and quantity in accordance with the goals and strategies of the organization. Workload analysis with Full-Time Equivalent (FTE) is the allocation of the total number of personnel needed to work on the entire transaction in a system / process at a certain time / period. The staff allocated includes full-time, part-time and short-hour. While the National Aeronautics and Space Administration Administration Task Load Index (NASA-TLX) method is a method used to analyze workers 'mental workload by measuring workers' subjective perceptions. This study will combine both methods to get the expected conclusions. This study aims to measure workload analysis aimed at making the workload between the sections in the Human Capital Bureau to be equally. The calculation results from the FTE stated that the workload contained in the Human Capital Bureau is still not evenly distributed, the recruitment and assessments section has a workload that tends to be low while other parts have a workload that tends to be high. Subjective workload that most affects is on the effort index, which is $24.09 \%$, followed by temporal demand of $21.64 \%$, performance aspects of $21.17 \%$, mental aspects of demand of 19.66\%, frustration level of 13, 44\%, and the physical demand aspect is $0 \%$.
\end{abstract}

Keywords-Workload, Workload Analysis, NASA-TLX FTE.

\section{INTRODUCTION}

PT. XYZ is a company in Indonesia engaged in manufacturing. In manufacturing companies such as PT XYZ This performance efficiency affects productivity in the working environment as well as the profitability that the company will gain. PT XYZ's problem is that there is an unbalanced workload in the employees in the Bureau of Human Capital, resulting in performance productivity. The organizational structure at Human Capital Bureau can be seen in Figure 1.

\footnotetext{
${ }^{1}$ Antonia Ratna Hanjani and Moses Laksono Singgih are with Department of Management Technology, Institut Teknologi Sepuluh Nopember, Indonesia. Email: ratna.antonia@gmail.com; moseslsinggih@ie.its.ac.id.
}

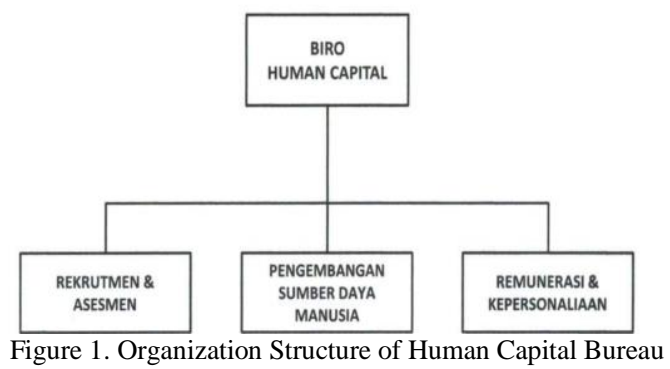

The absence of measurement of the workload can cause jealousy between individuals and excess stress found in the Bureau of Human Capital which results in less healthy conditions and decreased productivity. Based on overtime data in the Bureau of Human Capital, the recruitment and assessment sections tend to be less when compared to other parts of the Human Capital Bureau. This could result in a decrease in performance productivity at the bureau caused by an unbalanced level of workloads. In addition, this can result in social jealousy caused by the salary in the Bureau of Human Capital not balanced due to high overtime costs in certain parts.

Many works do not reach the target, resulting in the results of a Key Performance Index (KPI) Agency on this bureau tends to decline for the last 3 years. This can be due to the uninitiated HR initiative to conduct activities measured in KPI measurements. It can be said that the employee productivity at this bureau tends to decline. One cause of this productivity decline is that the workload received by the Bureau is not balanced with existing resources.

Therefore, the measurement of workload analysis is necessary. Prior to this measurement, analysis was conducted to define the job description per part measured from business process and organizational structure in Human Capital Bureau of PT XYZ. Measurement of this workload analysis is an important factor to determine the policy of human resources for the needs of employees.

The method used for this research is the National Aeronautics and Space Administration Task Load Index (NASA-TLX) and Full-Time Equivalent Employee (FTE) methods. The reason for using the FTE method is to know if the workload contained in the section of this bureau is evenly or it is still necessary to be made equally flat between the parts of this bureau. The reason for using the NASA-TLX method is to measure whether there is a possibility of mental workloads received by the Bureau 
already in accordance with the focus of the established work. If the results of the mental workload do not match the working focus, the performance productivity of the bureau will decline. The results of this measurement can also be used to predict the needs of employees in the Bureau of Human Capital to the future so that the productivity at the bureau can increase.

\section{METHOD}

\section{A. Workload Analysis}

Workload analysis is a way used to determine the time, effort, and resources that an organization needs to identify the actual need of human resources in quality and quantity according to organizational objectives and strategies [1]. While the workload has the meaning of a number of job targets or outcomes to be achieved in a single specific time unit. The reasons for the workload analysis[2] are:

1. Identifying the actual needs of human resources for quality and quality of human resources in the short or long term.

2. Identifying training needs for now and in the future.

3. Manage the number of employees in accordance with the established work system to increase employee productivity.

The challenge of workload analysis is that the subject cannot describe the natural activity when measured its workload, exploration of the work activity is incomplete, the subjects conducting activities outside the Company's defined standard activities, the formulation of Work activities performed very short, observation activities could not be seen at the time of observation, and observers were unable to establish work activity on the subject being observed [3]. The stages of workload measurement can be seen in Figures 2 and 3.

The objectives of the workload analysis are:

1. To identify the needs of employees of the quality or quantity now or for the future

2. As a measure of employee performance in a measured work of both working time and work

3. Leveling employees' workloads according to minimum employment needs and requirements

4. As a guide to improving skills when working and reference planning for development training for employees

Workload Measurement approach:

1. Physical measurements (cardio, respiratory, eye, and brain activity)

2. Subjective measurements (Modified Cooper-Harper Scale (MCH), NASA Task Load Index Scale (NASATLX), Subjective Workload Assessment Technique (SWAT))

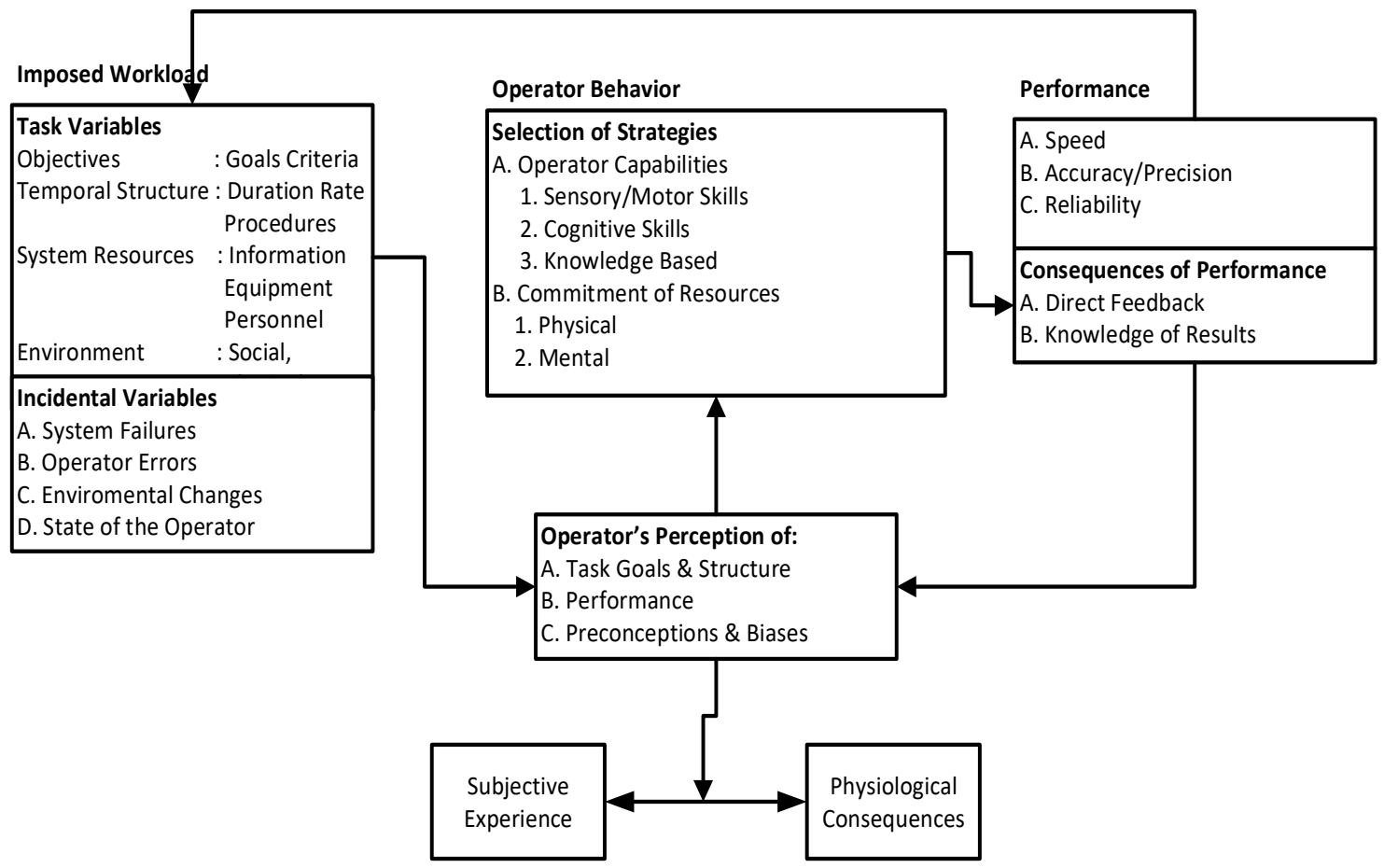

Figure 2. Variables that affect human performance and workload (Source: Hart,1981) 


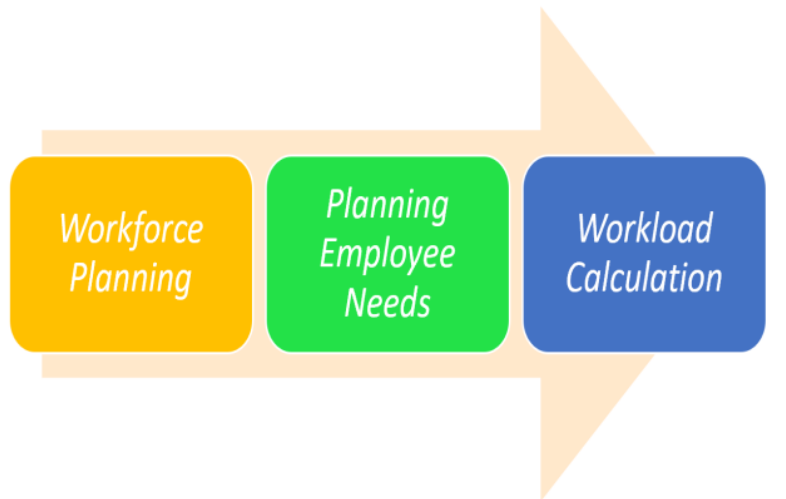

Figure 3. Stages of workload analysis (Source: Niebel, 2002)

\section{B. Relationship Between Workload and Productivity}

Workloads are very influential in the productivity of employees' performance because the environment and work capacity are aligned to productivity. If the burden received is too heavy, the employee productivity will decrease, otherwise if the workload is balanced then the employee productivity will increase [1]. The company needs to pay attention to every workload of its employees to achieve high productivity. Work productivity is influenced by workloads (physical, mental, social), additional load, and working capacity (age, gender). To improve the productivity of work in the company, the three factors must be balanced [4]. The relationship between work objectives and existing resources can be seen in Figure 4.

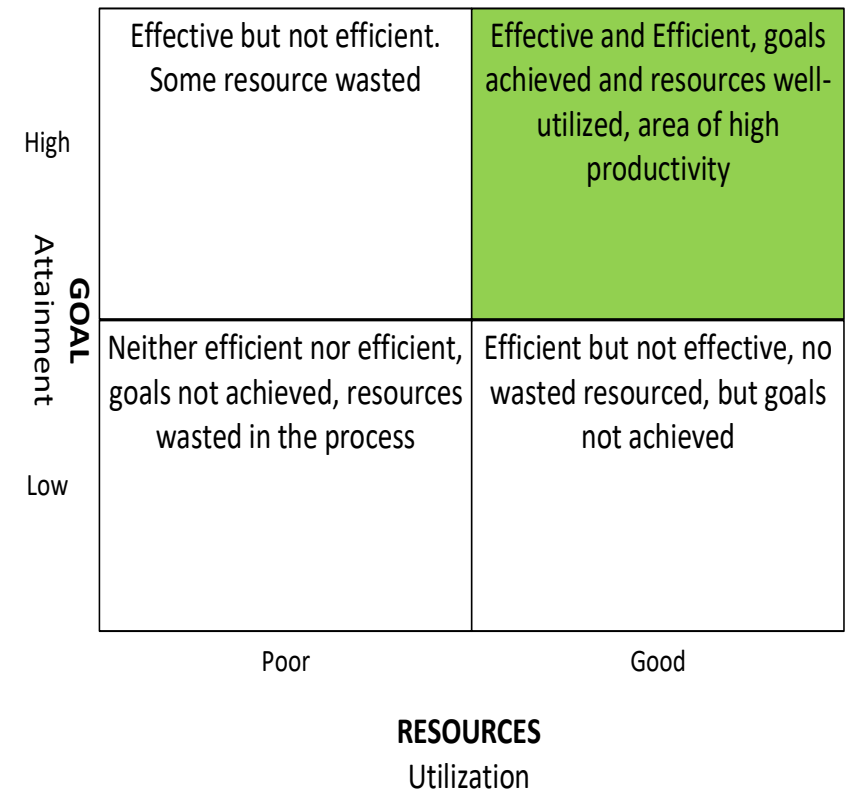

Figure 4. Relationship Between Work Objectives and Existing Resources

\section{NASA Task Load Index Scale (NASA-TLX)}

The NASA-TLX method is a method used to analyze worker's mental workloads by measuring the subjective perception of a worker [5]. The purpose of this measurement is to fulfill the needs of the measurement of the workload subjectively. The stages in this subjective measurement are:

1. Determine the job's mental workload factor

2. Specifying the range and interval of workload assessment

3. Select significant workload factors for specific tasks

4. Determining the impact of workload measurement results in continuation analysis

The objective of subjective workload measurement is to identify the factors of workload measurement results that significantly affect the work. In the calculation of NASATLX, the worker or respondent provides rating and weighted in each indicator in a pre-made questionnaire. The advantage of this method is that NASA-TLX is sensitive to a variety of job conditions, each assessment indicator is considered to be better able to provide results about the work, the decision-making system associated with the organization can be deduced faster and simple, and more precise and practical to implement in an operational environment [6]. The disadvantages of this calculation are that the subject more often fills the NASATLX form by claiming that the employee's workload is redundant, the emotions of the subject when the observation can be biased or not in accordance with the reality, and the level of trust management of NASA-TLX analysis. The form for the collection of calculation data of NASA-TLX can be seen in Figure 5. Can be seen on the form there are 6 dimensions of questions that will be answered by the subject by answering the rating specified in Figure 5. The rating range follows the NASA standard which is 1 (very low) and 21 (very high) or can also use a rating of between $0-100$. The subject can respond by marking on the distributed NASA-TLX form [7]. The indicators available on NASA-TLX can be seen in table 1 . The workload dimensions specified in NASA-TLX are:

1. Mentally needed (Mental Demand) is the demands of mental activity required to work (think, decide, remember)

2. Physical Demand is a physical activity needed when working (pushing, pulling)

3. The need of Time (Temporal Demand) is a perceived pressure of time during work

4. Performance (Own Performance) is a success in achieving the target task when working

5. Effort (Effort) is an effort issued by every individual mentally and physically needed to achieve the performance of the expected work

6. Levels of stress (Frustration Level) is a higher sense of insecurity, despair, stress, and uninterrupted than feeling safe, satisfied, suitable, comfortable, and the satisfaction of self-perceived during the work. 
The $1^{\text {st }}$ International Conference on Business and Management of Technology (IConBMT)

August 3rd 2019, Institut Teknologi Sepuluh Nopember, Surabaya, Indonesia

TABLE 1.

INDICATOR OF NASA-TLX

\begin{tabular}{|c|c|c|}
\hline Indicator & Scale & Description \\
\hline $\begin{array}{l}\text { Mental } \\
\text { Demand (MD) }\end{array}$ & Low - High & $\begin{array}{l}\text { How many mental and } \\
\text { perceptual activities needed } \\
\text { to see, to remember, and to } \\
\text { find. Whether the work is } \\
\text { easy or hard, simple or } \\
\text { complex, and loose or tight }\end{array}$ \\
\hline $\begin{array}{l}\text { Physical } \\
\text { Demand (PD) }\end{array}$ & Low - High & $\begin{array}{l}\text { How many physical activities } \\
\text { needed (e.g running, pulling, } \\
\text { etc.) }\end{array}$ \\
\hline $\begin{array}{l}\text { Temporal } \\
\text { Demand (TD) }\end{array}$ & Low - High & $\begin{array}{l}\text { How many pressure related to } \\
\text { the time felt during working. } \\
\text { Whether the work is slow, } \\
\text { relax, or fast and exhausting }\end{array}$ \\
\hline $\begin{array}{l}\text { Performance } \\
\text { (PD) }\end{array}$ & Poor-Good & $\begin{array}{l}\text { How big someone's success } \\
\text { in their work and how } \\
\text { satisfied them with their } \\
\text { working }\end{array}$ \\
\hline $\begin{array}{l}\text { Frustation } \\
\text { Level (FL) }\end{array}$ & Low - High & $\begin{array}{l}\text { How unsafe, desperate, } \\
\text { offended, and disturbing } \\
\text { compared to safe, satisfied, } \\
\text { and comfortable felt }\end{array}$ \\
\hline Effort (E) & Low - High & $\begin{array}{l}\text { How hard mental and } \\
\text { physical work needed to get } \\
\text { the work done }\end{array}$ \\
\hline
\end{tabular}

\section{NASA Task Load Index}

Hart and Staveland's NASA Task Load Index (TLX) method assesses work load on five 7-point scales. Increments of high, medium and low estimates for each point result in 21 gradations on the scales.

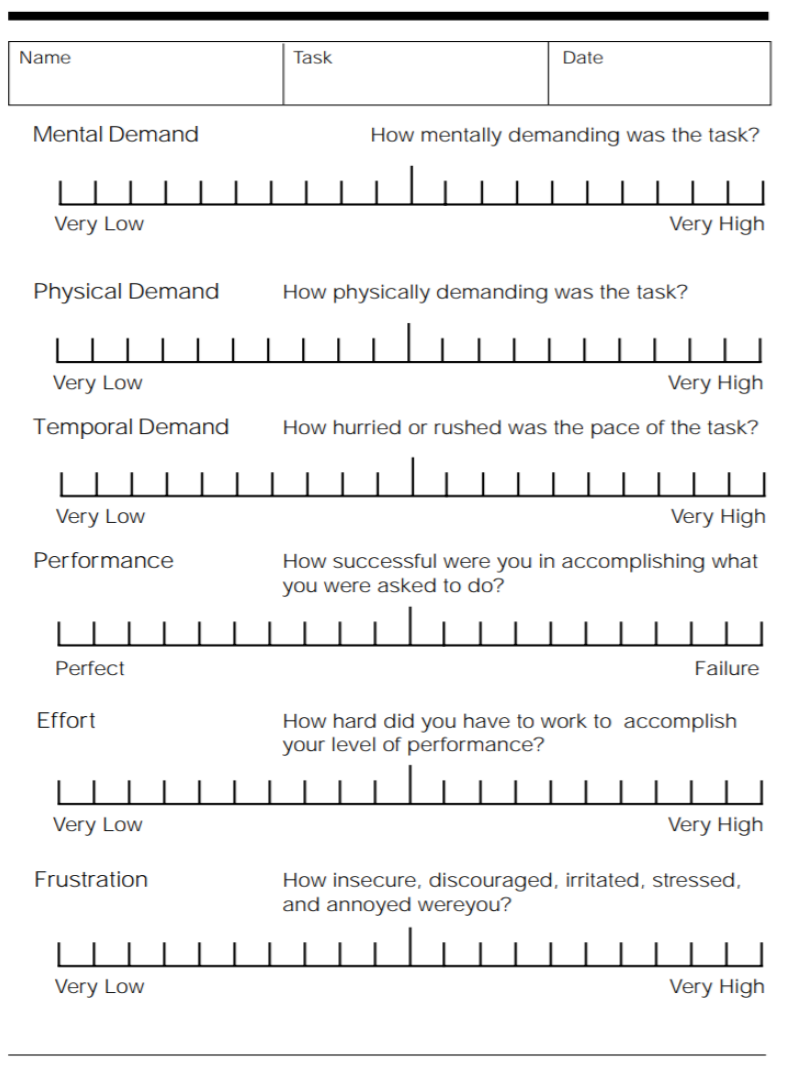

Figure 5. NASA-TLX's Questionnaire

\section{FTE}

FTE is the total number of personnel required to work on the entire transaction in a system/process at a certain time/period. The allocated employees include full-time, part-time, and short-hour. FTE refers to a measurement unit equivalent to an individual from a single work unit or school day, which applies in various contexts. FTE is commonly used to measure employees or students and/or their workloads.

FTE is most widely used by companies to determine the workload of their employees, with the aim of determining how many employees part-time and hours of their work. Every year, a company generally considers FTE worth 2.080 hours [8].

In a business or organization, especially those who employ a lot of employee part-time, turning work hours into FTE is important in order to help the company know how many employees are needed.

Ultimately, it is important for companies to define FTE due to a better understanding of its effectiveness and usability based on the amount of work done [9]. FTE obtained by dividing the total working hours with the total working hours effective in employees. Effective working hours are obtained by inserting a loose time employee when working or allowance times. Allowance times According to the International Labor Organization (ILO) can be seen in table 2 . The allowance Times category is as follows:

\section{1) Personal Allowances}

Personal or looseness of personal time are the looseness of time given by an organization for personal needs. Personal time looseness can be determined through full time study during working hours. For light activities administered about $2 \%-5 \%$ or approximately $10-25$ minutes of the total working hours per day, while for manual activity weight is given more than $5 \%$.

2) Fatigue Allowances

Fatigue or looseness of time caused by human capacity is the looseness of time given to provide the opportunity for workers or employees to unwind caused by heavy work to be done. Workloads can be physical workloads or mental workloads. The magnitude of time used for the calculation of this looseness time may vary according to the individual, the time interval of the job activity cycle, as well as the working environment conditions.

\section{3) Delay Allowances}

Delay or looseness of time caused by an unexpected condition of looseness of time calculated due to the anticipation of unavoidable or inevitable conditions as long as there is a schedule of work planning that compiled earlier. 
TABLE 2.

ILO'S INDEX OF ALLOWANCES

\begin{tabular}{|c|c|c|}
\hline \multicolumn{2}{|c|}{ A. Constant allowances: } & \multirow{3}{*}{$\begin{array}{l}5 \\
4\end{array}$} \\
\hline 1 & Personal allowance & \\
\hline 2 & Basic fatigue allowance & \\
\hline \multicolumn{3}{|c|}{ B. Variable allowances: } \\
\hline 1 & Standing allowance & 2 \\
\hline \multirow[t]{4}{*}{2} & Abnormal position allowance: & \\
\hline & a. Slightly awkward & 0 \\
\hline & b. Awkward (bending) & 2 \\
\hline & c. Very awkward (lying, stretching) & 7 \\
\hline \multirow[t]{14}{*}{3} & $\begin{array}{l}\text { Use of force, or muscular energy (lifting, pulling, or } \\
\text { pushing): }\end{array}$ & \\
\hline & Weight lifted, pounds: & \\
\hline & 5 & 0 \\
\hline & 10 & 1 \\
\hline & 15 & 2 \\
\hline & 20 & 3 \\
\hline & 25 & 4 \\
\hline & 30 & 5 \\
\hline & 35 & 7 \\
\hline & 40 & 9 \\
\hline & 45 & 11 \\
\hline & 50 & 13 \\
\hline & 60 & 17 \\
\hline & 70 & 22 \\
\hline \multirow[t]{4}{*}{4} & Bad light: & \\
\hline & a. Slightly below recommended & 0 \\
\hline & b. Well below & 2 \\
\hline & c. Quite inadequate & 5 \\
\hline 5 & Atmospheric conditions (heat and humidity)- variable & $0-100$ \\
\hline \multirow[t]{4}{*}{6} & Close attention: & \\
\hline & a. Fairly fine work & 0 \\
\hline & b. Fine or exacting & 2 \\
\hline & c. Very fine or very exacting & 5 \\
\hline \multirow[t]{5}{*}{7} & Noise level: & \\
\hline & a. Continuous & 0 \\
\hline & b. Intermittent - loud & 2 \\
\hline & c. Intermittent - very loud & 5 \\
\hline & d. High-pitched-loud & 5 \\
\hline \multirow[t]{4}{*}{8} & Mental strain: & \\
\hline & a. Fairly complex process & 1 \\
\hline & b. Complex or wide span of attention & 4 \\
\hline & c. Very complex & 8 \\
\hline \multirow[t]{4}{*}{9} & Monotony: & \\
\hline & a. Low & 0 \\
\hline & b. Medium & 1 \\
\hline & c. High & 4 \\
\hline \multirow[t]{4}{*}{10} & Tediousness: & \\
\hline & a. Rather tedious & 0 \\
\hline & b. Tedious & 2 \\
\hline & c. Very tedious & 5 \\
\hline
\end{tabular}

The formula used to calculate FTE can be seen in the following formula:

$$
\text { FTE: } \frac{\text { Total Process Time }}{\text { Effective Working Time }}
$$

After doing FTE calculation according to working hours in an organization, obtained calculation results. The indicator of whether the work is overcapacity or cannot be seen in Figure 6. If FTE < 1 means work capacity is very lacking. If FTE $=1$, the capacity of the work that exists in a division or part is sufficient. If FTE $>1$ means the capacity of the work in a division or part has been Beyond the limits of human abilities.

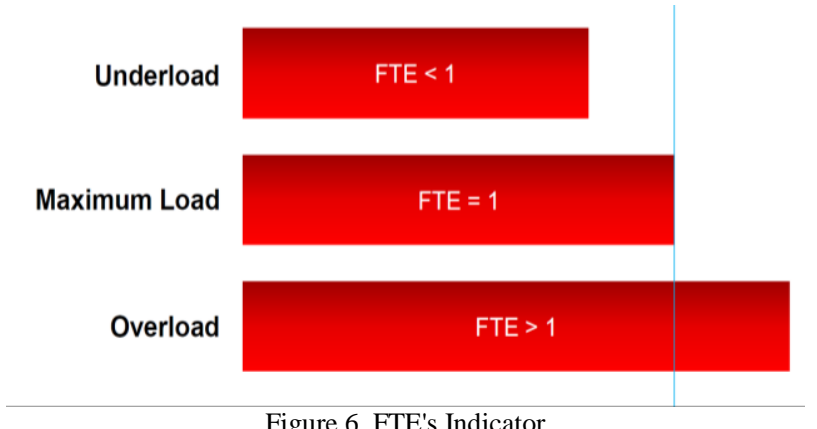

Figure 6. FTE's Indicator

\section{METHODOLOGY}

The steps used in drafting this study are divided into 4 stages, namely the data observation phase, data collection stage, data processing stage, and the conclusion drafting phase. The observation phase is the first phase of the study. This stage aims to collect data and measurement instruments that will be used in this research. The stages at the observation stage are business process mapping, organizational structure mapping, and job description and classification.

Data collection to be used for workload analysis calculations. The way that will be used in data collection is to use the interview according to the questionnaire previously drafted to the section in the Human Capital Bureau of PT XYZ. The next stage in data collection and processing is to process the results of the interview into NASA-TLX calculation. The reason why choosing the NASA-TLX method is that the criteria contained in this method can be applied in any field of work. If the final value of the NASA-TLX calculation is more than 70, then the mental burden received by the worker includes weight. If the final value of the calculation of NASA-TLX between $50-70$ then the burden of work received by the workers is included. If the final value of the NASA-TLX calculation is less than 50 then the mental burden received by the worker in the job includes light.

The next stage is doing FTE calculations. FTE is searched based on a pre-existing job description or if there is still no job description, has been identified at the previous stage. The implications of FTE value are divided into 3 types namely overload, normal, and underload. Based on workload analysis guidelines issued by the State 
Personnel Agency in 2010, the total value of FTE index that is above the value of 1.28 is considered overload, located between the value of 1 to 1.28 is considered normal/fit whereas if the value FTE index is between the value 0 to 0.99 is considered underload or the workload is still lacking. The result of the employee workload calculation is then verified by management to see its rarity. After verification, it can be followed by calculation of labor needs.

After calculating the workload analysis, the calculation is obtained. The result of the calculation will be used to develop the final conclusion in the form of working capacity as well as the expected recommendation will be used to align the workload in the section found in the Human Capital Bureau of PT XYZ. The steps used in this research can be seen in Figure 7.

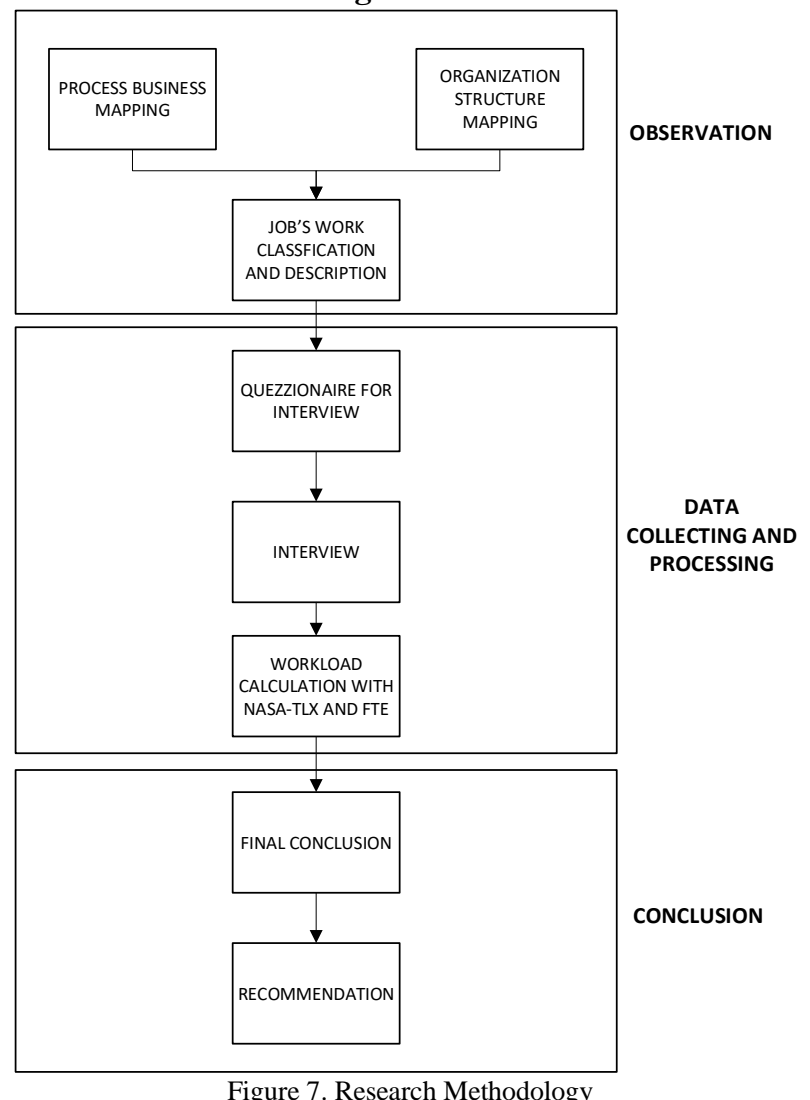

Figure 7. Research Methodology

\section{RESULTS AND DISCUSSION}

\section{A. Observation}

The Bureau of Human Capital at PT XYZ is instrumental in planning, coordinating and controlling all Human Resources (HR) activities through the smooth recruitment work Program \& Assessment, human resource development and remuneration \& Personalization in order to achieve a set of goals and objectives. The functions of this bureau are for the planning and fulfillment of human resources, career planning, placement optimization; Formulating and managing a company-level human resources information system; and development of human resources competence.

The Bureau of Human Capital has a workforce of 12 people spread into three parts of the bureau. The spread is 1 Manager Bureau, 3 section managers, 5 HR development staff, 2 staff at recruitment and assessment, and 4 staff in the Remuneration and personalization section. Normal working hours setting is from 07.30 until 16.30 for Mondays to Fridays. For rest hours from 12.00 to 12.45 for Mondays to Thursdays, and 11.15 to 13.15 for Fridays.

PT XYZ, especially in the Bureau of Human Capital, has a job description found in every section of the Bureau. This job description serves as a guideline and responsibility held by each employee who performs the task so that employees do not make mistakes with clarity in a job. At the Human Capital Bureau of PT XYZ, the job description is divided by the position of Bureau Manager, section manager, and staff and based on where the employee is assigned.

The recruitment and assessment department tasked is to plan, implement, control and develop the management of recruitment activities $\&$ assessment in accordance with the prevailing provisions in order to support the company's performance. The HR Management Section tasked is to plan, implement, control and develop management activities and human resource development in accordance with the quantity and quality required in order to improve and support company activities. Remuneration and personalization are responsible for planning, implementing, controlling and developing the management of administrative activities, maintenance personnel and the implementation of remuneration in order to improve and support the activities of the company. The job descriptions for each section and title can be seen in Tables 3,4, and 5 .

TABLE 3.

RECRUITMENT AND ASSESSMENT SECTION'S JOB DESCRIPTION

\begin{tabular}{cl}
\hline \hline No & Recruitment and Assessment Manager \\
\hline 1 & Evaluate the proposed human resources fulfillment strategy in accordance with the guidance of HR Bureau Manager \\
2 & Evaluate the company's budget work plan in accordance with the stipulated \\
3 & Evaluate the planning and procurement of qualified company workforce both in quantity and quality based on the company's workforce needs plan. \\
4 & $\begin{array}{l}\text { Evaluating proposed labor accrual, periodic salary increase/futures rank and mutation and/or increase in position (structural/weighted) are adjusted } \\
\text { to the plan of the Company's rules and/or the joint work Agreement. }\end{array}$
\end{tabular}


5 Foster and motivate subordinates and take action for those who violate in accordance with applicable regulations.

6 Evaluating the procurement of necessary human resources as well as mutations and education \& subordinate training to the head of the HR Department \& General

7 To submit periodical report on Program activities and achievements of recruitment section \& Assessment to the manager of HR Bureau \& General.

8 Evaluate the proposed human resources fulfillment strategy in accordance with the guidance of HR Bureau Manager

\begin{tabular}{cl}
\hline No & \multicolumn{1}{c}{ Recruitment and Assessment Staff } \\
\hline 1 & To develop proposed development methods, systems and procedures to further improve efficiency and productivity of work. \\
2 & To develop a proposed human resources fulfillment strategy in accordance with the guidance of HR Bureau Manager \\
3 & Develop a company budget work plan in accordance with the provisions stipulated \\
4 & $\begin{array}{l}\text { To develop the planning and procurement of qualified company workforce both in quantity and quality based on the company's manpower needs } \\
\text { plan. }\end{array}$ \\
5 & $\begin{array}{l}\text { Recommending proposed labor accrual, periodic salary increase/futures rank and mutation and/or increase in position (structural/weighted) are } \\
\text { adjusted to the plan of the Company's rules and/or the joint work Agreement. }\end{array}$ \\
6 & $\begin{array}{l}\text { Drafting and recommending the procurement of human resources needed as well as mutations and education \& subordinate training to the head of } \\
\text { the HR Department \& General }\end{array}$ \\
\hline \hline
\end{tabular}

TABLE 4.

HR DEVELOPMENT SECTION'S JOB DESCRIPTION

\begin{tabular}{|c|c|}
\hline \multicolumn{2}{|r|}{ Human Resource Development Manager } \\
\hline No & Job Description \\
\hline 1 & $\begin{array}{l}\text { Evaluate the development of methods, systems and work procedures to further improve efficiency and work productivity in the Human resources } \\
\text { development section. }\end{array}$ \\
\hline 2 & Evaluate the planning and development strategies of human resources based on the implementation of the HR Bureau manager. \\
\hline 3 & Evaluate the HR development plan for the formulation of the work plan \& budget of HR Bureau company. \\
\hline 4 & $\begin{array}{l}\text { Evaluate the implementation of department analysis activities for the establishment of Job Establishment of the company and conduct evaluation } \\
\text { for improvement and adjustment to organizational development. }\end{array}$ \\
\hline 5 & $\begin{array}{l}\text { Evaluating career Planning (Carreer Planning) in order to optimally develop: talents, knowledge, skills, expertise, and leadership in order to grow } \\
\text { employee loyalty. }\end{array}$ \\
\hline 6 & To compile and evaluate the education and training needs of every organizational unit in the company. \\
\hline 7 & $\begin{array}{l}\text { Plan and evaluate and coordinate the implementation of human resources development Program through education and training in the } \\
\text { management, knowledge, skills and skills and courses in and outside the company. }\end{array}$ \\
\hline 8 & $\begin{array}{l}\text { Establishing cooperation with the college, educational institutions, education Center \& Trainings, training centers, including government agencies } \\
\text { in the framework of cooperation in the field of trainings in particular and development of human resources in general. }\end{array}$ \\
\hline 9 & $\begin{array}{l}\text { Compile and evaluate information about higher education, Polytechnic, Institute of Management, Training center, Educational Center \& Trainings, } \\
\text { work Training hall, etc. }\end{array}$ \\
\hline 10 & Gather information about the realization of Education \& training held both in inside and outside the company. \\
\hline 11 & Evaluate the report of the results and usability, work paper, thesis, Work practices report, etc. \\
\hline 12 & Organizing organizations, especially project and workforce organizations. \\
\hline 13 & Proposed Education \& subordinate training to HR Bureau Manager \\
\hline 14 & Provide periodic reports about the Program activities and achievements of the Human resources Development Section to the HR Bureau manager. \\
\hline
\end{tabular}

\begin{tabular}{|c|c|}
\hline \multicolumn{2}{|r|}{ HR Development Staff } \\
\hline No & Job Description \\
\hline 1 & $\begin{array}{l}\text { To develop methods, systems and working procedures to further improve efficiency and work productivity in the Human resources development } \\
\text { section. }\end{array}$ \\
\hline 2 & To develop planning and human resources development strategy based on the implementation of the HR Bureau manager. \\
\hline 3 & To develop a working plan for human resource development in the framework of formulating \& project budget of HR Bureau. \\
\hline 4 & $\begin{array}{l}\text { To develop the implementation of Department analysis activities for the establishment of Job Establishment of the company and conduct } \\
\text { evaluation for improvement and adjustment to organizational development. }\end{array}$ \\
\hline
\end{tabular}


The $1^{\text {st }}$ International Conference on Business and Management of Technology (IConBMT)

August 3rd 2019, Institut Teknologi Sepuluh Nopember, Surabaya, Indonesia

5 To develop career planning (Carreer Planning) in order to optimally develop: talents, knowledge, skills, skills, and leadership in order to grow employee loyalty.

6 Compile and arrange education and training needs of every organizational unit in the company.

7 Plan and develop the implementation of human resources development Program through education and training in the management, knowledge, skills and skills and courses inside and outside the company.

8 Compiling a periodic report about the Program activities and achievements of the Human resources Development Section to the HR Bureau manager.

TABLE 5 .

REMUNERATION AND PERSONALIZATION SECTION'S JOB DESCRIPTION

\begin{tabular}{|c|c|}
\hline \multicolumn{2}{|r|}{ Remuneration and Personaliation section Manager } \\
\hline No & Job Description \\
\hline 1 & Evaluate personnel strategies and their programs based on implementation instructions from the Human Resources Bureau. \\
\hline 2 & Evaluate work plan remuneration Section \& Personnel in order to formulation of the work plan \& budget of HR Bureau company. \\
\hline 3 & Coordinating welfare administration, routine personnel services, BPJS services and Purna Bhakti employees. \\
\hline 4 & $\begin{array}{l}\text { Evaluate the size of transportation money, daily money, and other rights related to the travel agency, Detasering and employee assignments in } \\
\text { accordance with the provisions applicable to be appropriate and payable on time. }\end{array}$ \\
\hline 5 & Evaluate employee payroll and overtime work compensation. \\
\hline 6 & Coordinate the management of the company's property, whether the move is not moving, and to conduct a good adaministracy system. \\
\hline 7 & Evaluate the data and information about the instruction, employment regulations of the relevant government agencies. \\
\hline 8 & Controlling all personnel administration activities and archives/documents of employment. \\
\hline 9 & $\begin{array}{l}\text { Evaluate and publish and regulate the distribution of the decision letter of the Board of Directors and the assignment letter of the following } \\
\text { personnel in the file Personnel (national) }\end{array}$ \\
\hline 10 & Submit periodical reports about Program activities and Achievements remuneration section \& Personaliaan to HR Bureau Manager. \\
\hline \multicolumn{2}{|r|}{ Remuneration and Personaliation Section staff } \\
\hline No & Job Description \\
\hline 1 & Evaluate personnel strategies and their programs based on implementation instructions from the Human Resources Bureau. \\
\hline 2 & Evaluate work plan remuneration Section \& Personnel in order to formulation of the work plan \& budget of HR Bureau company. \\
\hline 3 & Coordinating welfare administration, routine personnel services, BPJS services and retired employees. \\
\hline 4 & $\begin{array}{l}\text { Evaluate the size of transportation money, daily money, and other rights related to the travel agency, Detasering and employee assignments in } \\
\text { accordance with the provisions applicable to be appropriate and payable on time. }\end{array}$ \\
\hline 5 & Evaluate employee payroll and overtime work compensation. \\
\hline 6 & Coordinate the management of the company's property, whether the move is not moving, and to conduct a good adaministracy system. \\
\hline 7 & Evaluate the data and information about the instruction, employment regulations of the relevant government agencies. \\
\hline 8 & Controlling all personnel administration activities and archives/documents of employment. \\
\hline 9 & $\begin{array}{l}\text { Evaluate and publish and regulate the distribution of the decision letter of the Board of Directors and the assignment letter of the following } \\
\text { personnel in the file Personnel (national) }\end{array}$ \\
\hline 10 & Submit periodical reports about Program activities and Achievements remuneration section \& Personaliaan to HR Bureau Manager. \\
\hline
\end{tabular}

\section{B. Data Collection and Processing}

1) Observation Results with FTE

This FTE measurement method is done with the aim of simplifying performance measurements by changing the workload hours to the number of people needed to accomplish a specific task. FTE measurements in this study use interview and observation methods for approximately 1 month to staff and related section managers to figure out the comparison between jobs and the amount of time required to complete Job. The value of allowance or allowance for employees according to the International Labor of Organization (ILO) table can be seen in Table 6.
The result of FTE gained from total working time divided by the total effective time of work. The calculation result of FTE can be seen in Table 7.

TABLE 6. ALLOWANCES INDEX

\begin{tabular}{clc}
\hline No & \multicolumn{1}{c}{ Allowances } & Percentage (\%) \\
\hline 1 & Work at the table & 3 \\
2 & Sitting position & 1 \\
3 & Normal view & 3 \\
4 & Normal temperature & 3 \\
5 & Temporal needs & 5 \\
\hline & Total & $\mathbf{1 5}$ \\
\hline
\end{tabular}


TABLE 7.

Calculation Results of FTE

\begin{tabular}{lcc}
\hline \hline \multicolumn{1}{c}{ Position } & FTE Index & Description \\
\hline Recruitment and Assessment Manager & 0,36 & Underload \\
Human resources development Manager & 1,83 & overload \\
Remuneration \& Personalization Manager & 1,07 & Fit \\
Recruitment Staff 1 & 0,62 & Underload \\
Recruitment Staff 2 & 0,62 & Underload \\
HR Development Staff 1 & 1,03 & Fit \\
HR Development Staff 2 & 1,30 & Overload \\
HR Development Staff 3 & 1,32 & Overload \\
HR Development Staff 4 & 1,33 & Overload \\
Remuneration \& Personaliation Staff 1 & 1,02 & Fit \\
Remuneration \& Personaliation Staff 2 & 1,33 & fit \\
\hline \hline
\end{tabular}

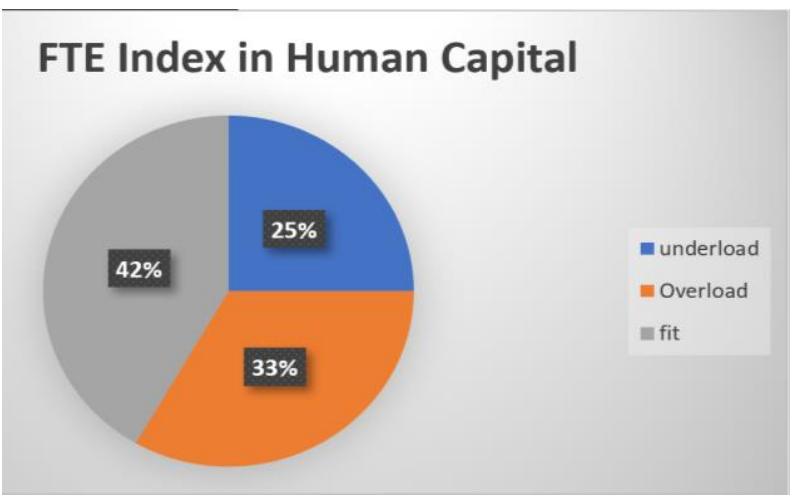

Figure 8. Pie Chart of FTE Index

It can be seen on the chart in Figure 8 that the workload on the Human Capital Bureau is still uneven. In the recruitment and assessment sections are still likely to have a low workload while in the HR development section tends to have a high workload. Uneven workloads between parts of this bureau that are likely to cause work productivity in the bureau are likely to decline.

\section{2) Observation Results with NASA-TLX}

Observations using NASA-TLX were used to measure the mental workload on the section of the Human Capital Bureau of PT XYZ. This observation step is to find the weighted from the questionnaire filling, create a rating table, create table weighted workload, make the interpretation of the score NASA-TLX, and make analysis of the interpretation results of NASA-TLX score. The indicator comparison questionnaire is distributed to different sections of the Human Capital Bureau. From the results of the different 3-part questionnaire then performed recapitulation on the number of tally questionnaire given. The rating is obtained from a questionnaire that has been filled based on information from the section in the Bureau of Human Capital. Employees are required to provide a rating on the mental load indicators and the rating provided is subjective according to the employee's subjective burden of each job. Product value is obtained by multiplying the rating by weight. Therefore, there are 6 products for 6 indicators in each employee. The WWL value is derived from the total product value per research object. Workload gained from WWL value divided by 15 . The result of the NASA-TLX's calculation can be seen in Table 8. Of the Weighted Workload average value (WWL) obtained, it is then linked to the NASA-TLX score to determine the workload class. The interpretation result of workload measurement with NASA-TLX can be seen in Table 9.

TABLE 8.

NASA-TLX'S WORKLOAD CALCULATION

\begin{tabular}{|c|c|c|c|c|c|c|c|c|}
\hline \multirow{2}{*}{ Object } & \multicolumn{6}{|c|}{ Value } & \multirow{2}{*}{ WWL } & \multirow{2}{*}{ Workload } \\
\hline & MD & PD & TD & $\mathbf{P}$ & $\mathbf{E}$ & FL & & \\
\hline $\begin{array}{l}\text { Recruitment and } \\
\text { Assessment Manager }\end{array}$ & 120 & 0 & 325 & 50 & 120 & 90 & 705 & 47 \\
\hline $\begin{array}{l}\text { Human Resources } \\
\text { Development } \\
\text { Manager }\end{array}$ & 90 & 0 & 140 & 340 & 180 & 60 & 810 & 54 \\
\hline $\begin{array}{l}\text { Remuneration and } \\
\text { Personaliation } \\
\text { Manager }\end{array}$ & 135 & 0 & 270 & 360 & 110 & 225 & 1100 & 73 \\
\hline Recruitment Staff 1 & 90 & 0 & 220 & 90 & 300 & 30 & 730 & 49 \\
\hline Recruitment Staff 2 & 150 & 0 & 160 & 150 & 210 & 135 & 805 & 54 \\
\hline $\begin{array}{l}\text { HR Development } \\
\text { Staff } 1\end{array}$ & 340 & 0 & 135 & 190 & 380 & 170 & 1215 & 81 \\
\hline $\begin{array}{l}\text { HR Development } \\
\text { Staff } 2\end{array}$ & 255 & 0 & 240 & 270 & 240 & 80 & 1085 & 72 \\
\hline $\begin{array}{l}\text { HR Development } \\
\text { Staff } 3\end{array}$ & 285 & 0 & 180 & 165 & 200 & 55 & 885 & 59 \\
\hline $\begin{array}{l}\text { HR Development } \\
\text { Staff } 4\end{array}$ & 375 & 0 & 120 & 240 & 195 & 130 & 1060 & 71 \\
\hline $\begin{array}{l}\text { Remuneration and } \\
\text { Personaliation Staff } 1\end{array}$ & 50 & 0 & 285 & 210 & 340 & 270 & 1155 & 77 \\
\hline $\begin{array}{l}\text { Remuneration and } \\
\text { Personaliation Staff } 2\end{array}$ & 195 & 0 & 220 & 180 & 280 & 180 & 1055 & 70 \\
\hline
\end{tabular}

\begin{tabular}{lcc}
\multicolumn{4}{c}{ TABLE 9. NASA-TLX'S WORKLOAD CATEGORY } \\
\hline \hline \multicolumn{1}{c}{ Object } & Workload & Category \\
\hline Recruitment and Assessment Manager & 47 & Light \\
Human resources development Manager & 54 & Moderate \\
Remuneration and Personaliation Manager & 73 & Heavy \\
Recruitment Staff 1 & 49 & Light \\
Recruitment Staff 2 & 54 & Moderate \\
HR Development Staff 1 & 81 & Heavy \\
HR Development Staff 2 & 72 & Heavy \\
HR Development Staff 3 & 59 & Moderate \\
HR Development Staff 4 & 71 & Heavy \\
Remuneration and Personaliation Staff 1 & 77 & Heavy \\
Remuneration and Personaliation Staff 2 & 70 & Heavy \\
\hline \hline
\end{tabular}

Based on the score obtained, it can be noted that 2 employees (18.18\%) has a lightweight, subjective workload, 3 employees (27.27\%) A moderate subjective 
workload, and 6 employees (54.55\%) have a heavy subjective workload. The results showed that most of the employees at the Human Capital Bureau at PT XYZ had a heavy subjective workload. Employees who feel they have the most severe subjective workloads located in the HR Development section. Based on the NASA-TLX data processing that has been done in the previous stage, it can be known which aspect is the most dominant. The results of the score element comparison on NASA-TLX can be seen in Table 10.

TABLE 10.

COMPARISON ON NASA-TLX'S ELEMENT

\begin{tabular}{ccc}
\hline \hline Factor & Score & Percentage \\
\hline MD & 2085 & $19,66 \%$ \\
PD & 0 & $0 \%$ \\
TD & 2295 & $21,64 \%$ \\
P & 2245 & $21,17 \%$ \\
E & 2555 & $24,09 \%$ \\
FL & 1425 & $13,44 \%$ \\
\hline \hline
\end{tabular}

Based on the total and percentage gained in each aspect, it can be noted that the effort aspect is the subjective aspect that best affects the magnitude of the subjective workload based on NASA-TLX of $24.09 \%$, followed by temporal demand, performance, mental demand, and frustration levels. The effort or business aspect reveals how hard the effort is needed in completing a job. This is to say that most of the employees in the Human Capital Bureau feel that the business needed in completing a job is considered high. Employees of the Bureau of Human Capital are required to complete the work at a certain time and if the work is deemed impossible to be resolved in accordance with the target, these employees are required to work outside business.

\section{Comparative interpretation of workload analysis results}

This subchapter is attached to the interpretation results of the comparison of workload analysis between the results of observation with FTE and NASA-TLX methods. Results of comparisons between workload analysis calculations on this bureau can be seen in Table 11. In Table 11, it can be seen that although the work received by the employees is sufficient according to the working capacity, the stress of work felt by employees at this bureau tends to be high. This is in line with the role of the superiors gained from the observation in the previous stage that is lacking in two-way communication so that the stress of work is felt high enough because employees feel less appreciated as workers.

TABLE11.

NASA-TLX'S WORKLOAD CATEGORY

\begin{tabular}{|c|c|c|c|}
\hline Position & $\begin{array}{l}\text { FTE } \\
\text { Calculation }\end{array}$ & $\begin{array}{l}\text { NASA-TLX } \\
\text { Calculation }\end{array}$ & Interpretation \\
\hline $\begin{array}{l}\text { Recruitment and } \\
\text { Assessment Manager }\end{array}$ & Underload & Light & The workload received is not large and balanced work stress is not heavy \\
\hline $\begin{array}{l}\text { Human Resources } \\
\text { Development Manager }\end{array}$ & Overload & Moderate & $\begin{array}{l}\text { The work received by this employee is too much but this employee is not very } \\
\text { overwhelmed with the situation }\end{array}$ \\
\hline $\begin{array}{l}\text { Remuneration and } \\
\text { Personaliation Manager }\end{array}$ & Fit & Heavy & $\begin{array}{l}\text { The work received by this employee is already in accordance with capacity but these } \\
\text { employees feel the work received makes excessive stress }\end{array}$ \\
\hline Recruitment Staff 1 & Underload & Light & $\begin{array}{l}\text { The work undertaken by these employees tends to be below average capacity and is } \\
\text { balanced also with these employees feel that the stress of work received is very mild } \\
\text { because it }\end{array}$ \\
\hline Recruitment Staff 2 & Underload & Moderate & $\begin{array}{l}\text { Acceptable work tends to be lower than capacity but it feels that mental workloads tend } \\
\text { to be somewhat high. }\end{array}$ \\
\hline HR Development Staff 1 & Fit & Heavy & $\begin{array}{l}\text { The work received by this employee is already in accordance with the working capacity } \\
\text { but the employee feels that the stress of work gained tends to be severe. }\end{array}$ \\
\hline HR Development Staff 2 & Overload & Heavy & $\begin{array}{l}\text { The work received by these employees tends to be excessive compared to the working } \\
\text { capacity resulting in the stress of work experienced also tends to weigh }\end{array}$ \\
\hline HR Development Staff 3 & Overload & Moderate & $\begin{array}{l}\text { The work received by these employees tends to overdo the working capacity resulting in } \\
\text { the stress of work experienced is also somewhat high }\end{array}$ \\
\hline HR Development Staff 4 & Overload & Heavy & $\begin{array}{l}\text { The work received by these employees tends to be excessive compared to the working } \\
\text { capacity resulting in the stress of work experienced also tends to weigh }\end{array}$ \\
\hline $\begin{array}{l}\text { Remuneration and } \\
\text { Personaliation Staff } 1\end{array}$ & Fit & Heavy & $\begin{array}{l}\text { Work received by this employee is already in accordance with the working capacity but } \\
\text { need to be investigated further causes of occupational stress are likely to be high }\end{array}$ \\
\hline $\begin{array}{l}\text { Remuneration and } \\
\text { Personaliation Staff } 2\end{array}$ & Fit & Heavy & $\begin{array}{l}\text { Work received by this employee is already in accordance with the working capacity but } \\
\text { need to be investigated further causes of occupational stress are likely to be high }\end{array}$ \\
\hline
\end{tabular}




\section{Recommendation}

Determination of the number of workers in this bureau is done by comparing the total FTE index with the workload that employees must bear for each job position. The needs of the number of workers can be seen in Table 12.

TABLE 12.

NEEDS OF THE NUMBER OF WORKERS

\begin{tabular}{lccl}
\hline \hline \multicolumn{1}{c}{ Position } & FTE & Total Workers & Conclusion \\
\hline $\begin{array}{l}\text { Recruitment and } \\
\text { Assessment }\end{array}$ & 1,6 & 2 & Enough \\
HR Development & 6,81 & 4 & $\begin{array}{l}\text { Add-on 2 } \\
\text { personnel }\end{array}$ \\
$\begin{array}{l}\text { Remuneration and } \\
\text { Personalisation }\end{array}$ & 3,42 & 2 & $\begin{array}{l}\text { Add-on 1 } \\
\text { personnel }\end{array}$ \\
\hline \hline
\end{tabular}

Based on the results of the final score calculations based on NASA-TLX It is known that 6 employees feel that the subjective workload received tends to be high. Aspects of subjective workloads based on NASA-TLX are the highest in the effort aspect. One effort to reduce that aspect is to do the addition of personnel. The Table 13 shows the changes to the NASA-TLX final score when the number of personnel is performed based on FTE calculation. In the simulation the results of the comparison can be noted that the subjective workload can be reduced when the addition of personnel. The subjective workload became lightweight and the opportunity to increase productivity on the bureau increased because employees felt that the highest scoring effort on aspects of workloads according to NASA-TLX were low.

TABLE 13.

COMPARISON BEFORE AND AFTER CONDITION

\begin{tabular}{lccc}
\hline \hline \multicolumn{1}{c}{ Position } & $\begin{array}{c}\text { Total } \\
\text { Score }\end{array}$ & $\begin{array}{c}\text { Beginning } \\
\text { Condition }\end{array}$ & $\begin{array}{c}\text { After add-on's } \\
\text { Condition }\end{array}$ \\
\hline $\begin{array}{l}\text { Recruitment and } \\
\text { Assessment }\end{array}$ & 102 & 51,17 & 51,17 \\
HR Development & 283 & 70,75 & 47,17 \\
$\begin{array}{l}\text { Remuneration and } \\
\text { Personalisation }\end{array}$ & 147 & 73,67 & 49,11 \\
\hline \hline
\end{tabular}

To make optimal employee performance so as to increase productivity can also be done by changing the workforce composition according to the calculation of the optimal workforce position and making changes and drafting on the description Work on the part of the Human capital Bureau that has measured its workload so that the workload incurred can be distributed evenly. In the development of HR will be reduced the description of his work to be moved to the part that the workload is still less likely to be low, namely in the recruitment and assessment. Employee performance can also be improved by adding or leveling the number of existing personnel so that the workload can be evenly distributed.

\section{CONCLUSION}

After conducting research on the analysis of workload on the Bureau of Human Capital at PT XYZ, can be withdrawn as follows:

1. Based on the final score obtained by FTE, can be found in the recruitment section and the assessment has a total FTE 1.6 with the number of employees 2 people who can be concluded that the employee in this section corresponds to the workload experienced, part The development of human resources has a total FTE 6.81 with a workforce of 4 people that can be concluded that there need to be additional 2 personnel, and in the remuneration and Personalization has the index FTE 3.42 with the number of workers 2 that can be concluded that there must be 1 additional personnel.

2. Based on the workload calculation according to NASATLX, it is known that 2 employees have a lightweight subjective workload, 3 employees have moderate subjective workloads, and 6 employees have heavy workloads.

3. Based on the score index on NASA-TLX can be noted also that the most subjective workload affecting the effort index is as much as $24.09 \%$, followed by temporal demand by $21.64 \%$, the performance aspect of $21.17 \%$, the mental aspect Demand of $19.66 \%$, aspect frustration level of $13.44 \%$, and physical demand aspect of $0 \%$. One of the causes of the high effort aspect of this bureau is the pressure of the boss will be the task to be completed.

4. Proposals given after the analysis of workload calculations based on FTE and NASA-TLX is to do the addition of employee personnel, especially in the development of human resources and remuneration section to reduce the subjective workload on The Bureau. In addition, another proposal is to change the composition of the workforce, review the job descriptions in each section of the Bureau, and flatten the workload in each section of the Human capital Bureau.

\section{REFERENCES}

[1] N. A. Stanton, Handbook of Human Factors and Ergonomics Methods. Boca Raton, Florida: CRC Press, 2006.

[2] United States Agency for International Development (USAID), "A methodology to analyze workload in public sector organizationa." pp. 1-4, 2011.

[3] S. C. Bommer and M. Fendley, "A theoretical framework for evaluating mental workload resources in human systems design for manufacturing operations," Int. J. Ind. Ergon., vol. 63, pp. 7-17, 2018.

[4] E. Management, C. W. Bay, and H. Kong, "Simplifed subjective workload assessment technique," no. 1992, pp. 229-243, 2001. S. G. Hart and L. E. Staveland, "Development of NASA-TLX (Task Load Index)," Adv. Psychol., vol. 52, pp. 139-183, 1988. S. Rubio, E. Diaz, J. Martin, and J. M. Puente, "Evaluation of subjective mental workload: A comparison of SWAT, NASATLX, and workload profile methods," Appl. Psychol., vol. 53, no. 1 , pp. 61-86, 2004.

[7] H. L. Tubbs-Cooley, C. A. Mara, A. C. Carle, and A. P. Gurses, 
The $1^{\text {st }}$ International Conference on Business and Management of Technology (IConBMT)

August 3rd 2019, Institut Teknologi Sepuluh Nopember, Surabaya, Indonesia

"The NASA Task Load Index as a measure of overall workload among neonatal, paediatric and adult intensive care nurses," Intensive Crit. Care Nurs., vol. 46, pp. 64-69, 2018.

[8] Kementerian Pendayagunaan Aparatur Negara, "Pedoman Perhitungan Kebutuhan Pegawai Berdasarkan Beban Kerja Dalam Rangka Penyusunan Formasi PNS.” Kementerian
Pendayagunaan Aparatur Negara, 2004.

[9] R. Jones, "Physical Ergonomic and Mental Workload Factors of Mobile Learning Affecting Performance of Adult Distance Learners: Student Perspective," University of Central Florida, 2009. 